Supplement of Biogeosciences, 18, 1067-1080, 2021 https://doi.org/10.5194/bg-18-1067-2021-supplement (C) Author(s) 2021. This work is distributed under the Creative Commons Attribution 4.0 License.

(c) (1)

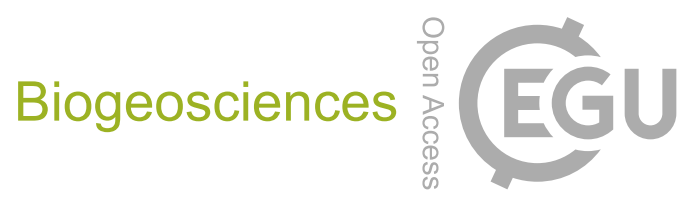

Supplement of

\title{
Biotic and abiotic transformation of amino acids in cloud water: experi- mental studies and atmospheric implications
}

Saly Jaber et al.

Correspondence to: Anne-Marie Delort (a-marie.delort@uca.fr)

The copyright of individual parts of the supplement might differ from the CC BY 4.0 License. 
Table S1: Composition of the artificial cloud medium used for biotic and abiotic transformation of amino acids in microcosms.

\begin{tabular}{|c|c|c|c|}
\hline $\begin{array}{c}\text { Chemical } \\
\text { species }\end{array}$ & $\begin{array}{c}\text { Concentration } \\
(\boldsymbol{\mu M})\end{array}$ & $\begin{array}{c}\text { Chemical } \\
\text { species }\end{array}$ & $\begin{array}{c}\text { Concentration } \\
(\boldsymbol{\mu} \mathbf{M})\end{array}$ \\
\hline Acetate & 100 & cysteine & 1 \\
\hline Formiate & 72.5 & glutamic acid & 1 \\
\hline Succinate & 7.5 & glycine & 1 \\
\hline Oxalate & 15 & histidine & 1 \\
\hline $\mathrm{Cl}^{-}$ & 200 & isoleucine & 1 \\
\hline $\mathrm{NO}_{3}{ }^{-}$ & 400 & lysine & 1 \\
\hline $\mathrm{SO}_{4}{ }^{2-}$ & 25 & methionine & 1 \\
\hline $\mathrm{Na}^{+}$ & 1000 & phenylalanine & 1 \\
\hline $\mathrm{NH}_{4}{ }^{+}$ & 400 & proline & 1 \\
\hline $\mathrm{K}^{+}$ & 25 & serine & 1 \\
\hline $\mathrm{Mg}^{2+}$ & 50 & threonine & 1 \\
\hline $\mathrm{Ca}^{2+}$ & 200 & tryptophan & 1 \\
\hline alanine & 1 & tyrosine & 1 \\
\hline arginine & 1 & valine & 1 \\
\hline asparagine & 1 & glutamine & pH \\
\hline aspartic acid & 1 & & \\
\hline & & & 1 \\
\hline
\end{tabular}

15

a The $\mathrm{pH}$ of the artificial cloud medium was adjusted to 6 (a few drops of $\mathrm{NaOH}$ at $1.38 \mathrm{M}$ and of $0.39 \mathrm{M} \mathrm{H}_{2} \mathrm{SO}_{4}$ ) and the medium was sterilized by filtration on a polyethersulphone (PES) membrane of $0.20 \mu \mathrm{m}$ porosity (Fisher Scientific) before use. Note that cysteine was present in the medium but it could not be assayed by LC-HRMS, neither leucine that cannot be 20 distinguished from isoleucine by LC-HRMS. 
Table S2: Retention times, exact masses and LODs and LOQs measured for the 18 AA measured by UPLC-HRMS

\begin{tabular}{|c|c|c|c|c|c|}
\hline Amino acid & $\begin{array}{l}\text { Molecular } \\
\text { formula }\end{array}$ & $\begin{array}{l}\text { Retention } \\
\text { time (min) }\end{array}$ & $\begin{array}{c}\mathbf{m} / \mathbf{z} \\
{[\mathbf{M}+\mathbf{H}]}\end{array}$ & LOD $(\mu \mathrm{M})$ & LOQ $(\mu \mathrm{M})$ \\
\hline ALA & $\mathrm{C}_{3} \mathrm{H}_{7} \mathrm{NO}_{2}$ & 4.25 & 90.0550 & 0.237 & 0.474 \\
\hline $\mathrm{ARG}$ & $\mathrm{C}_{6} \mathrm{H}_{14} \mathrm{~N}_{4} \mathrm{O}_{2}$ & 7.41 & 175.1190 & 0.072 & 0.143 \\
\hline ASN & $\mathrm{C}_{4} \mathrm{H}_{8} \mathrm{~N}_{2} \mathrm{O}_{3}$ & 5.57 & 133.0608 & 0.143 & 0.286 \\
\hline ASP & $\mathrm{C}_{4} \mathrm{H}_{7} \mathrm{NO}_{4}$ & 5.09 & 134.0448 & 0.148 & 0.295 \\
\hline GLN & $\mathrm{C}_{5} \mathrm{H}_{10} \mathrm{~N}_{2} \mathrm{O}_{3}$ & 5.35 & 147.0764 & 0.234 & 0.468 \\
\hline GLU & $\mathrm{C}_{5} \mathrm{H}_{9} \mathrm{NO}_{4}$ & 4.8 & 148.0526 & 0.111 & 0.222 \\
\hline GLY & $\mathrm{C}_{2} \mathrm{H}_{5} \mathrm{NO}_{2}$ & 4.6 & 76.0393 & 0.242 & 0.483 \\
\hline HIS & $\mathrm{C}_{6} \mathrm{H}_{9} \mathrm{~N}_{3} \mathrm{O}_{2}$ & 7.47 & 156.0768 & 0.094 & 0.188 \\
\hline ILE & $\mathrm{C}_{6} \mathrm{H}_{13} \mathrm{NO}_{2}$ & 2.59 & 160.1081 & 0.179 & 0.359 \\
\hline LYS & $\mathrm{C}_{6} \mathrm{H}_{14} \mathrm{~N}_{2} \mathrm{O}_{2}$ & 7.62 & 147.1128 & 0.069 & 0.139 \\
\hline MET & $\mathrm{C}_{5} \mathrm{H}_{11} \mathrm{NO}_{2} \mathrm{~S}$ & 2.69 & 150.0584 & 0.072 & 0.144 \\
\hline PHE & $\mathrm{C}_{9} \mathrm{H}_{11} \mathrm{NO}_{2}$ & 2.64 & 166.0863 & 0.061 & 0.122 \\
\hline PRO & $\mathrm{C}_{5} \mathrm{H}_{9} \mathrm{NO}_{2}$ & 3.05 & 116.0706 & 0.140 & 0.281 \\
\hline SER & $\mathrm{C}_{3} \mathrm{H}_{7} \mathrm{NO}_{3}$ & 5.36 & 106.0499 & 0.135 & 0.268 \\
\hline THR & $\mathrm{C}_{4} \mathrm{H}_{9} \mathrm{NO}_{3}$ & 4.87 & 120.0655 & 0.163 & 0.327 \\
\hline TRP & $\mathrm{C}_{11} \mathrm{H}_{12} \mathrm{~N}_{2} \mathrm{O}_{2}$ & 2.65 & 205.0972 & 0.058 & 0.117 \\
\hline TYR & $\mathrm{C}_{9} \mathrm{H}_{11} \mathrm{NO}_{3}$ & 7.46 & 182.0812 & 0.072 & 0.143 \\
\hline VAL & $\mathrm{C}_{5} \mathrm{H}_{11} \mathrm{NO}_{2}$ & 2.61 & 118.0863 & 0.237 & 0.475 \\
\hline
\end{tabular}


Table S3: Relative standard deviation (RSD = Standard deviation/mean) for each AA based on calibration curves ( 3 technical replicates).

\begin{tabular}{|c|c|c|c|}
\hline & \multicolumn{3}{|c|}{$\begin{array}{l}\text { Relative Standard Deviation } \\
\text { (RSD = Standard deviation/mean) }\end{array}$} \\
\hline Amino acid & $0.1 \mu \mathrm{M}(\mathrm{n}=3)$ & $0.5 \mu \mathrm{M}(\mathrm{n}=3)$ & $1 \mu M(n=3)$ \\
\hline ALA & & $0.71 \%$ & $3.61 \%$ \\
\hline ARG & $0.83 \%$ & $1.96 \%$ & $1.56 \%$ \\
\hline ASN & $5.23 \%$ & $4.92 \%$ & $3.63 \%$ \\
\hline$\overline{\text { ASP }}$ & & $10.77 \%$ & $5.96 \%$ \\
\hline GLN & $4.19 \%$ & $4.37 \%$ & $3.20 \%$ \\
\hline GLU & $3.77 \%$ & $2.89 \%$ & $3.92 \%$ \\
\hline GLY & & & $21.39 \%$ \\
\hline HIS & $0.62 \%$ & $0.89 \%$ & $1.22 \%$ \\
\hline ILE & $4.48 \%$ & $0.48 \%$ & $0.59 \%$ \\
\hline LYS & $6.64 \%$ & $1.96 \%$ & $1.50 \%$ \\
\hline MET & $4.49 \%$ & $4.35 \%$ & $6.38 \%$ \\
\hline PHE & $4.63 \%$ & $1.68 \%$ & $1.02 \%$ \\
\hline PRO & $11.67 \%$ & $5.08 \%$ & $1.28 \%$ \\
\hline SER & $14.34 \%$ & $3.06 \%$ & $3.20 \%$ \\
\hline THR & $14.15 \%$ & $3.67 \%$ & $1.06 \%$ \\
\hline TRP & $7.00 \%$ & $1.67 \%$ & $1.75 \%$ \\
\hline TYR & $0.94 \%$ & $1.81 \%$ & $1.15 \%$ \\
\hline VAL & $17.94 \%$ & $2.98 \%$ & $11.41 \%$ \\
\hline
\end{tabular}


35 Table S4: Rate constants for 18 amino acids for the $\mathrm{OH}, \mathrm{O}_{3}$ and ${ }^{1} \mathrm{O}_{2}$ reactions. As most rate constants are only available at or near room temperature, we chose this temperature for all constants.

\begin{tabular}{|c|c|c|c|c|c|c|}
\hline & $\begin{array}{c}\text { кон / } \\
\mathbf{M}^{-1} \mathbf{s}^{-1}\end{array}$ & Reference & $\begin{array}{c}\text { ko3/ } \\
M^{-1} \mathbf{s}^{-1}\end{array}$ & Reference & $\begin{array}{l}\mathbf{k}_{102} / \\
M^{-1} s^{-1}\end{array}$ & Reference \\
\hline ALA & $7.7 \cdot 10^{7}$ & (Scholes et al., 1965) & $2.5 \cdot 10^{1}$ & $\begin{array}{l}\text { Ignatenko and } \\
\text { Cherenkevich, 1985) }\end{array}$ & $2 \cdot 10^{6}$ & $\begin{array}{l}\text { (Matheson and Lee, } \\
\text { 1979) }\end{array}$ \\
\hline$\overline{\mathrm{ARG}}$ & $3.5 \cdot 10^{9}$ & (Buxton et al., 1988) & $2.8 \cdot 10^{2}$ & $\begin{array}{l}\text { (gnatenko and } \\
\text { Cherenkevich, 1985) }\end{array}$ & $<1 \cdot 10^{6}$ & $\begin{array}{l}\text { (Kraljić and } \\
\text { Sharpatyi, 1978) }\end{array}$ \\
\hline $\mathrm{ASN}$ & $4.9 \cdot 10^{7}$ & $\begin{array}{l}\text { (MASUDA et al., } \\
\text { 1973) }\end{array}$ & $7.0^{\circ} \cdot 10^{1}$ & $\begin{array}{l}\text { (gnatenko and } \\
\text { Cherenkevich, 1985) }\end{array}$ & & \\
\hline$\overline{\text { ASP }}$ & $4.9 \cdot 10^{7}$ & $\begin{array}{l}\text { (MASUDA et al., } \\
\text { 1973) }\end{array}$ & $5.0^{\circ} \cdot 10^{1}$ & $\begin{array}{l}\text { (Ignatenko and } \\
\text { Cherenkevich, 1985) }\end{array}$ & & \\
\hline GLN & $5.4 \cdot 10^{8}$ & $\begin{array}{l}\text { (MASUDA et al., } \\
\text { 1973) }\end{array}$ & $8.0 \cdot 10^{1}$ & $\begin{array}{l}\text { (Ignatenko and } \\
\text { Cherenkevich, 1985) }\end{array}$ & & \\
\hline GLU & $1.6 \cdot 10^{8}$ & (Scholes et al., 1965) & $2 \cdot 10^{-1}$ & $\begin{array}{l}\text { (Ignatenko and } \\
\text { Cherenkevich, 1985) }\end{array}$ & $5.0 \cdot 10^{5}$ & $\begin{array}{l}\text { (McGregor and } \\
\text { Anastasio, 2001) }\end{array}$ \\
\hline GLY & $1.7 \cdot 10^{7}$ & (Scholes et al., 1965) & $2.1 \cdot 10^{1}$ & $\begin{array}{l}\text { (Ignatenko and } \\
\text { Cherenkevich, 1985) }\end{array}$ & $<1 \cdot 10^{5}$ & $\begin{array}{l}\text { (Michaeli and } \\
\text { Feitelson, 1994) }\end{array}$ \\
\hline HIS & $5 \cdot 10^{9}$ & $\begin{array}{l}\text { (Motohashi and Saito, } \\
\text { 1993) }\end{array}$ & $3.9 \cdot 10^{3}$ & $\begin{array}{l}\text { (Ignatenko and } \\
\text { Cherenkevich, 1985) }\end{array}$ & $6 \cdot 10^{7}$ & $\begin{array}{l}\text { (McGregor and } \\
\text { Anastasio, 2001) }\end{array}$ \\
\hline ILE & $1.8 \cdot 10^{9}$ & $\begin{array}{l}\text { (MASUDA et al., } \\
1973)\end{array}$ & & & & \\
\hline LYS & $3.5 \cdot 10^{8}$ & $\begin{array}{l}\text { (MASUDA et al., } \\
\text { 1973) }\end{array}$ & $1.2 \cdot 10^{2}$ & $\begin{array}{l}\text { (Ignatenko and } \\
\text { Cherenkevich, 1985) }\end{array}$ & & \\
\hline MET & $8.5 \cdot 10^{9}$ & (Adams et al., 1965) & $410^{6}$ & (Pryor et al., 1984) & $2.1 \cdot 10^{7}$ & $\begin{array}{l}\text { (Miskoski and García, } \\
1993 \text { ) }\end{array}$ \\
\hline PHE & $6.5 \cdot 10^{9}$ & (Buxton et al., 1988) & $1.3 \cdot 10^{3}$ & $\begin{array}{l}\text { (Ignatenko and } \\
\text { Cherenkevich, 1985) }\end{array}$ & $7 \cdot 10^{5}$ & $\begin{array}{l}\text { (Michaeli and } \\
\text { Feitelson, 1994) }\end{array}$ \\
\hline PRO & $6.5 \cdot 10^{8}$ & $\begin{array}{l}\text { (MASUDA et al., } \\
\text { 1973) }\end{array}$ & $4.8 \cdot 10^{2}$ & $\begin{array}{l}\text { (Ignatenko and } \\
\text { Cherenkevich, 1985) }\end{array}$ & & \\
\hline SER & $2.5 \cdot 10^{8}$ & (Scholes et al., 1965) & $1.8 \cdot 10^{2}$ & $\begin{array}{l}\text { (Ignatenko and } \\
\text { Cherenkevich, 1985) }\end{array}$ & & \\
\hline THR & $5.1 \cdot 10^{8}$ & $\begin{array}{l}\text { (MASUDA et al., } \\
\text { 1973) }\end{array}$ & $2.6 \cdot 10^{2}$ & $\begin{array}{l}\text { (Ignatenko and } \\
\text { Cherenkevich, 1985) }\end{array}$ & & \\
\hline
\end{tabular}




\begin{tabular}{|c|c|c|c|c|c|c|}
\hline TRP & $1.3 \cdot 10^{10}$ & (Buxton et al., 1988) & $5.6 \cdot 10^{4}$ & $\begin{array}{l}\text { (Ignatenko and } \\
\text { Cherenkevich, 1985) }\end{array}$ & $4.1 \cdot 10^{7}$ & $\begin{array}{l}\text { (McGregor and } \\
\text { Anastasio, 2001) }\end{array}$ \\
\hline TYR & $1.3 \cdot 10^{10}$ & (Solar et al., 1984) & $4.8 \cdot 10^{3}$ & $\begin{array}{l}\text { (Ignatenko and } \\
\text { Cherenkevich, 1985) }\end{array}$ & $5 \cdot 10^{6}$ & $\begin{array}{l}\text { (McGregor and } \\
\text { Anastasio, 2001) }\end{array}$ \\
\hline VAL & $8.5 \cdot 10^{8}$ & $\begin{array}{lll}\text { (Prütz and Vogel, } \\
\text { 1976) }\end{array}$ & $4 \cdot 10^{1}$ & $\begin{array}{l}\text { Ignatenko and } \\
\text { Cherenkevich, 1985) }\end{array}$ & & \\
\hline
\end{tabular}


40 Table S5: Selected experimental studies of amino acid oxidation by various oxidants. Note that the experimental conditions were not necessarily atmospherically-relevant. Products are only listed to demonstrate the wide variety of possible reaction pathways and products.

\begin{tabular}{|c|c|c|c|}
\hline Amino acid & Oxidant & Main product(s) & Reference \\
\hline ARG & $\begin{array}{l}\text { Fenton } \\
\text { chemistry }\end{array}$ & glutamic semialdehyde & $\begin{array}{l}\text { (Stadtman, 1993; Stadtman and } \\
\text { Levine, 2003) and reference therein }\end{array}$ \\
\hline ASP & $\mathrm{OH}$ & $\mathrm{NH}_{3}$,Malonic, oxalic and formic acids & (Marion et al., 2018) \\
\hline CYS & $\begin{array}{l}\text { Fenton } \\
\text { chemistry }\end{array}$ & -S-S-disulfide cross-links & $\begin{array}{l}\text { (Stadtman, 1993; Stadtman and } \\
\text { Levine, 2003) }\end{array}$ \\
\hline GLY & $\mathrm{OH}$ & Oxalic, formic, oxamic acids & (Berger et al., 1999) \\
\hline GLY & $\mathrm{O}_{3}$ & Nitrate, nitrites & (Berger et al., 1999) \\
\hline $\begin{array}{l}\text { GLY-ALA- } \\
\text { VAL-PRO } \\
\text { peptides }\end{array}$ & $\mathrm{OH}$ & Hydroperoxides, alcohols & (Morgan et al., 2012) \\
\hline HIS & $\mathrm{O}_{3}$ & PRO & (Mudd et al., 1969) \\
\hline HIS & $\begin{array}{l}\text { Fenton } \\
\text { chemistry }\end{array}$ & ASP, ASN, 2-oxoimidazoline & $\begin{array}{l}\text { (Stadtman, 1993; Stadtman and } \\
\text { Levine, 2003) and references therein }\end{array}$ \\
\hline LEU & $\mathrm{OH}$ & $\begin{array}{l}\text { Isovaleric acid and other carbonyl } \\
\text { compounds }\end{array}$ & \\
\hline LYS & $\begin{array}{l}\text { Fenton } \\
\text { chemistry }\end{array}$ & 2-amino-adipicsemialdehyde & $\begin{array}{l}\text { (Stadtman, 1993; Stadtman and } \\
\text { Levine, 2003) and references therein }\end{array}$ \\
\hline MET & $\mathrm{O}_{3}$ & Methionine sulfoxide & (Mudd et al., 1969) \\
\hline PHE & ROS & TYR & $\begin{array}{l}\text { (Stadtman, 1993; Stadtman and } \\
\text { Levine, 2003) }\end{array}$ \\
\hline PHE & $\begin{array}{l}\text { Direct UV } \\
\text { absorption }\end{array}$ & TYR & (Pattison et al., 2012) \\
\hline PRO & $\begin{array}{l}\text { Fenton } \\
\text { chemistry }\end{array}$ & $\begin{array}{l}\text { GLU, pyroglutamate, } \\
\text { Cis/trans-4-hydroxyproline, } \\
\text { 2-pyrrolidone, } \\
\text { glutamic semialdehyde }\end{array}$ & $\begin{array}{l}\text { (Stadtman, 1993; Stadtman and } \\
\text { Levine, 2003) and reference therein }\end{array}$ \\
\hline SER & $\mathrm{OH}$ & carbonyl and carboxylic acid & \\
\hline THR & $\begin{array}{l}\text { Fenton } \\
\text { chemistry }\end{array}$ & 2-amino-3-ketobutyric acid & $\begin{array}{l}\text { (Stadtman, 1993; Stadtman and } \\
\text { Levine, 2003) and references therein }\end{array}$ \\
\hline THR & $\mathrm{O}_{3}$ & Dihydroxyphenylalanine & (Mudd et al., 1969) \\
\hline TRP & $\mathrm{OH}$ & Formic and acetic acids, many aromatic & (Bianco et al., 2016) \\
\hline
\end{tabular}




\begin{tabular}{|c|c|c|c|}
\hline & & intermediates & \\
\hline TRP & ${ }^{1} \mathrm{O}_{2}$ & $\begin{array}{l}\text { 3a-hydroxypyrroloindole; } N \text { - } \\
\text { formylkynurenine, kynurenine, } 3 \alpha- \\
\text { dihydroxypyrroloindole. }\end{array}$ & \\
\hline TYR & $\mathrm{OH}$ & Enedial & (Prasse et al., 2018) \\
\hline TYR & $\begin{array}{l}\text { Fenton } \\
\text { chemistry }\end{array}$ & Tyr-Tyr cross-links & $\begin{array}{l}\text { (Stadtman, 1993; Stadtman and } \\
\text { Levine, 2003) and references therein }\end{array}$ \\
\hline TYR & $\begin{array}{l}{ }^{1} \mathrm{O}_{2} \text { or } \\
\text { direct UV } \\
\text { absorption }\end{array}$ & $\begin{array}{l}\text { 3a-hydroxy-6-oxo-2,3,3a,6,7,7a- } \\
\text { hexahydro-1H-indol-2-carboxylic acid }\end{array}$ & \\
\hline
\end{tabular}

45

50

55

60

65 

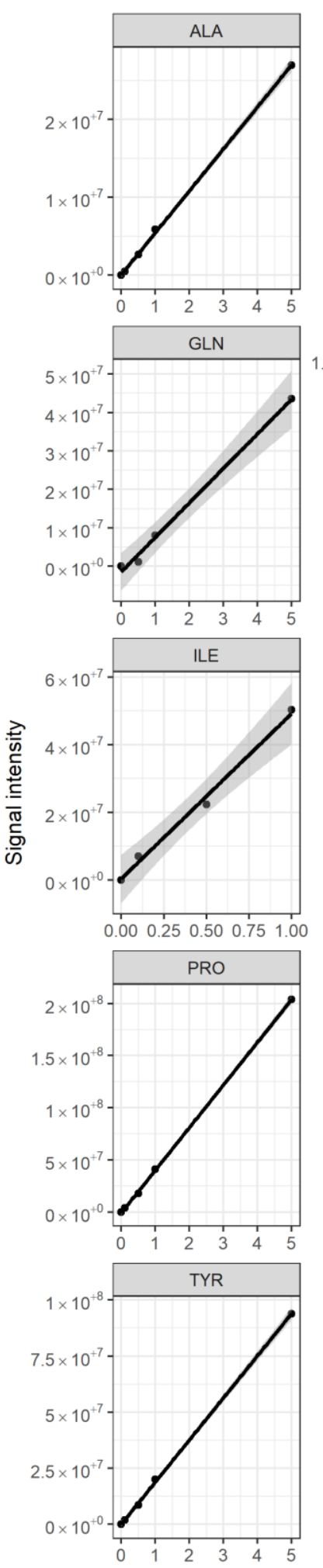
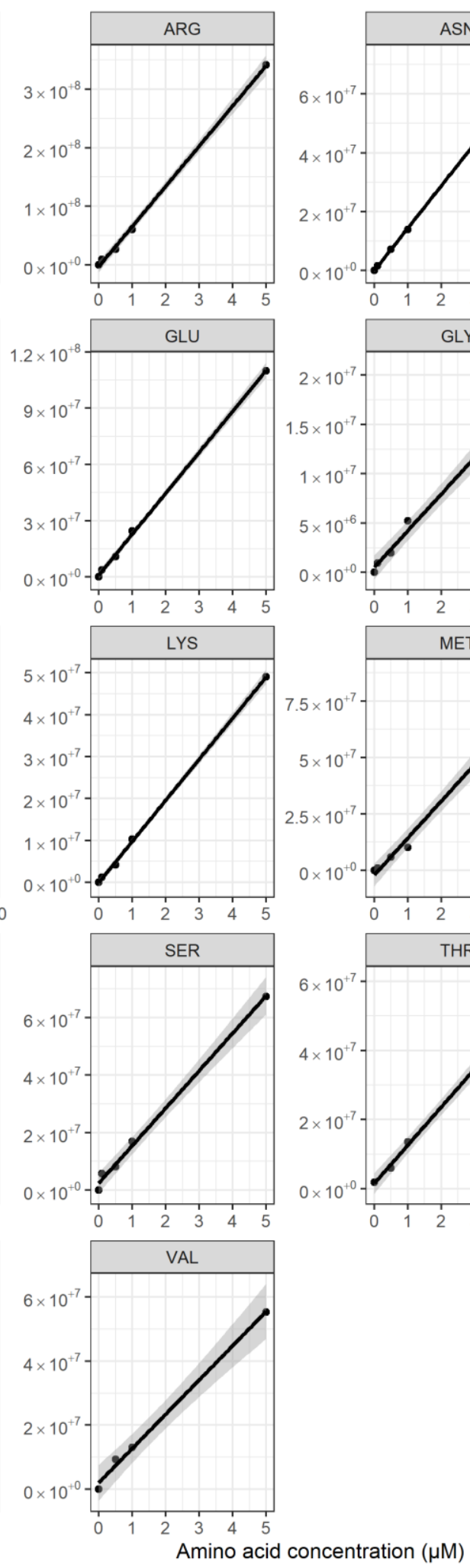
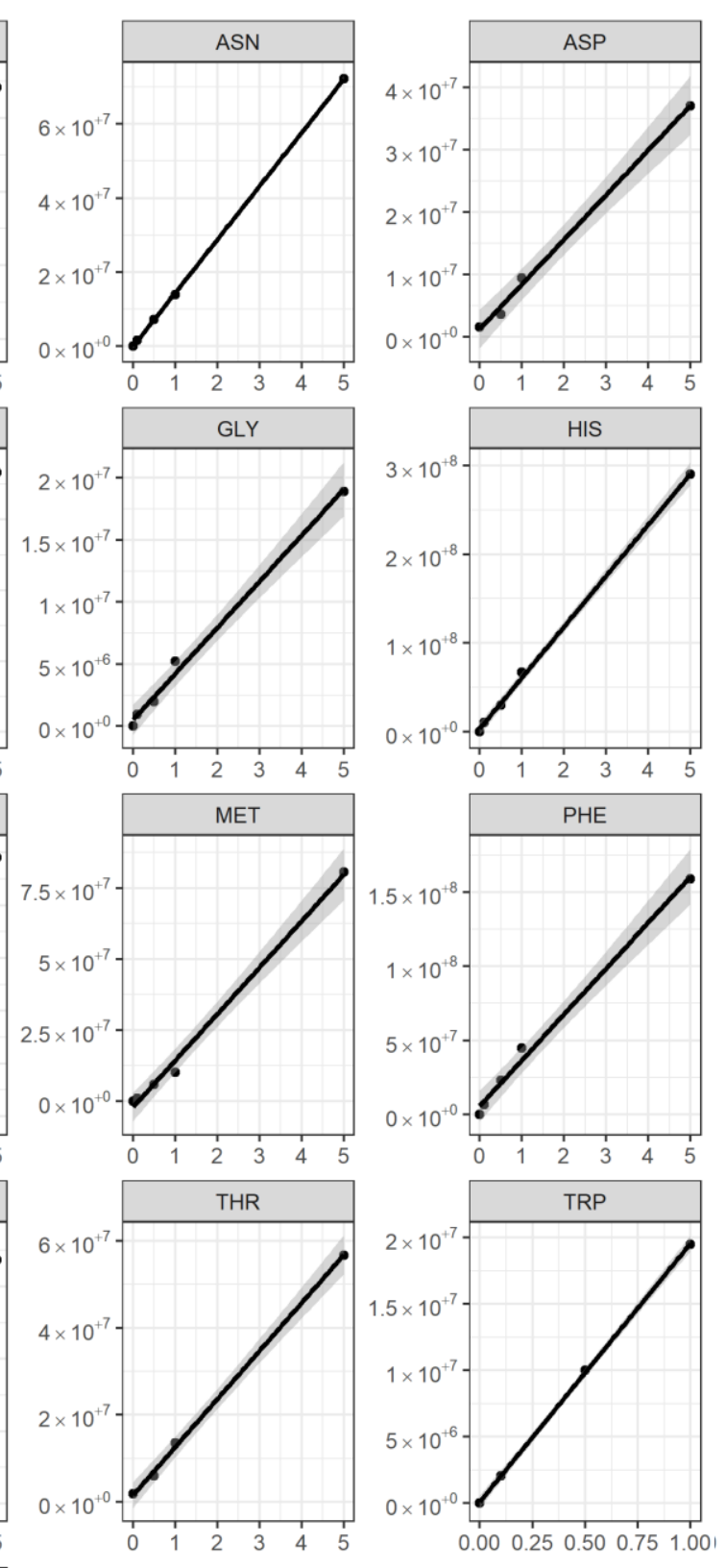

Figure S1: Calibration curves for LC-HRMS experiments 


\section{Example of biodegradation rate calculation:}

Bacterial degradation of amino acids follows a first order decay equation as $C_{t}=C_{0} . e^{-k t}$ with $t$ the incubation time, $C_{0}$ and $C_{t}$ the initial concentration and concentration at $t$ respectively and $k$ the first order decay constant.

First, concentration of each amino acid is followed through time (Figure S2A) by LC-HRMS as described in the Materials and Methods section. Values are converted to determine $k$ corresponding to the slope of $\operatorname{Ln}\left(C_{t} / C_{0}\right)=f(t)($ Figure S2B)

Biodegration rates are then calculated as follows: $V_{b}=\frac{k \times C_{0}}{N_{\text {cell }}}$ with $V_{b}$ the biodegradation rate (in $\mathrm{mol} \mathrm{h}^{-1}$ cell $^{-1}$ ), $k$ the first order decay constant (in $\mathrm{h}^{-1}$ ), $C_{0}$ the initial concentration in aminoacid (in mol L ${ }^{-1}$ ) and $N_{\text {cell }}$ the bacterial concentration (in cell $\mathrm{L}^{-1}$ ).

In this example, $N_{\text {cell }}=410^{8}$ cell L $\mathrm{L}^{-1}$ and $C_{0}=1.1610^{-6} \mathrm{~mol} \mathrm{~L}^{-1}$ so $\mathrm{V}_{\mathrm{b}}=8.8810^{-16} \mathrm{~mol} \mathrm{~h}^{-1}$ cell $^{-}$ 1
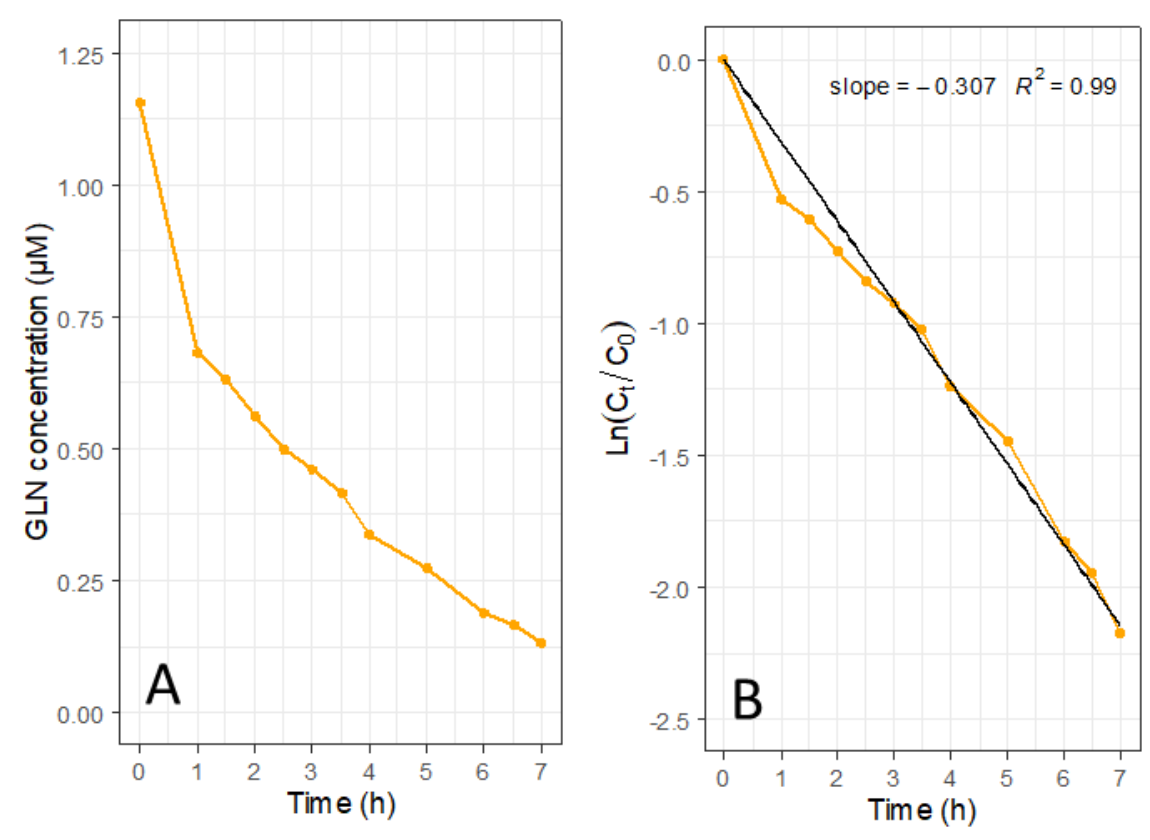

Figures S2: Example of calculation of the biodegradation rate of GLN. A) time dependence of GLN concentration with time measured by LC-HRMS. B) $\ln \left(\mathrm{Ct} / \mathrm{C}_{0}\right)=\mathrm{f}(\mathrm{t})$, degradation rates are calculated from the slope at the origin.

$\mathrm{C}_{\mathrm{t}}$ : GLN measured concentration at time $=\mathrm{t}, \mathrm{C}_{0}$ :GLN measured concentration at time zero. 


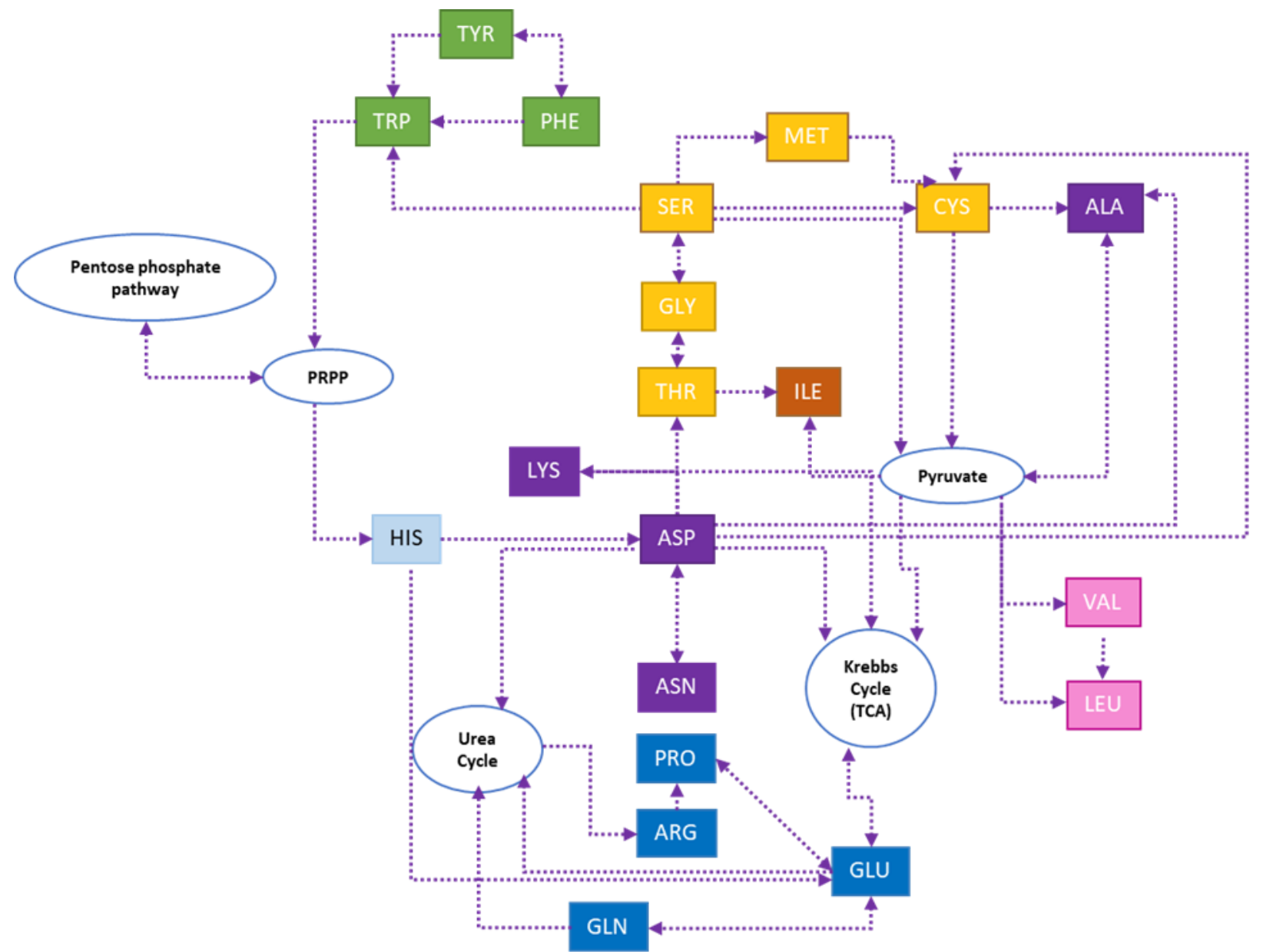

Figure S3: Main metabolic routes for AA metabolism according to (KEGG pathway database, n.d.) 

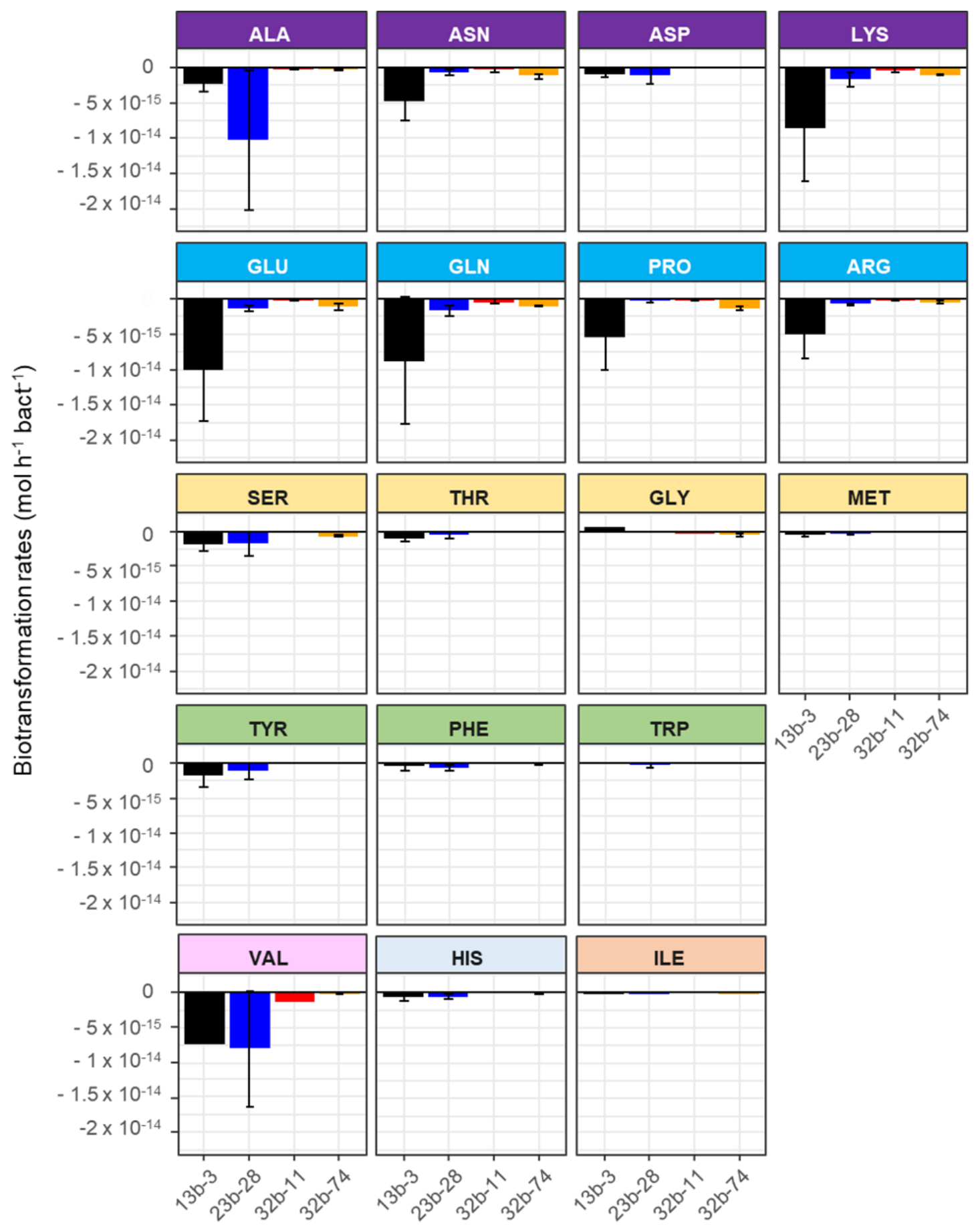

Figure S4: Biotransformation rates $\left(m o l\right.$ bact $\left.^{-1} \mathrm{~h}^{-1}\right)$ of AA by the four bacterial strains grouped according the metabolic pathways of the AA (see Figure S3). Pseudomonas graminis PDD-13b-3 in black, Rhodococcus enclensis PDD-23b-28 in blue, Sphingomonas sp. PDD32b-11 in red and Pseudomonas syringae PDD-32b-74 in orange). The standard error bars reflect the rather important biological variability measured from 3 triplicates (independent incubations). Positive values correspond to a biosynthesis process, negative values to a biodegradation process. 

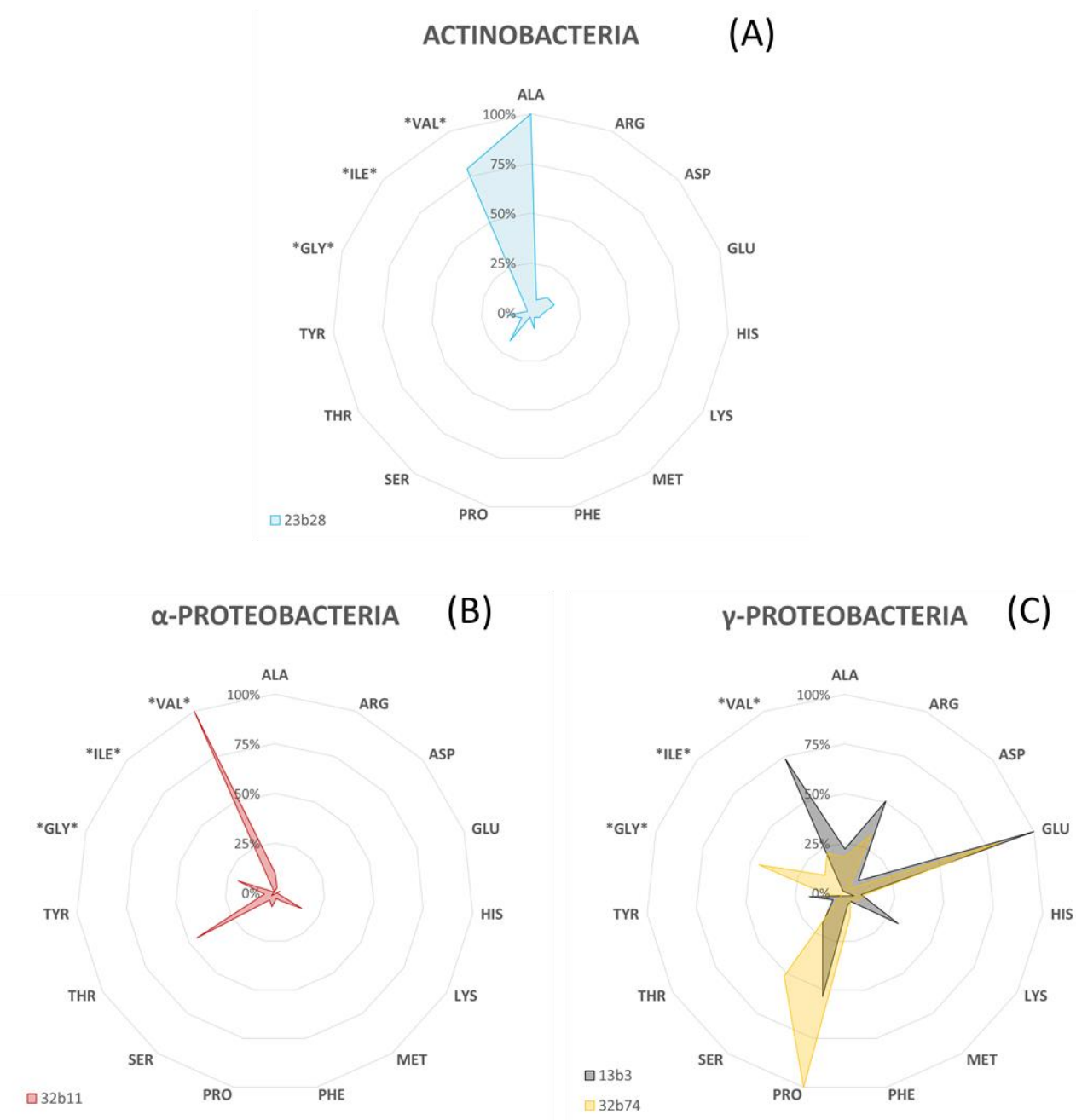

Figure S5: Comparison of the ability of the different strains to metabolize amino acids according to their phylogeny: (A) Actinobacteria (Rhodococcus enclensis PDD-23b-28 in blue), B) $\alpha$ Proteobacteria (Sphingomonas sp PDD-32b-11 in red), (C) $\gamma$-Proteobacteria (Pseudomonas graminis PDD-13b-3 in black and Pseudomonas syringae PDD-32b-74 in yellow). The rates of biodegradation (average from 3 replicates) are presented as a \% for each amino acid in the form of a radar plot. For each strain the highest rate is put at $100 \%$. (* only one replicate value was available).

An example of phylogenetic classification is given bellow

Phylum-- $\rightarrow$ Class $\rightarrow$ Genus $\rightarrow$ species $\rightarrow$ strain number

Proteobacteria $\rightarrow \gamma$-Proteobacteria $\rightarrow$ Pseudomonas $\rightarrow$ graminis $\rightarrow$ PDD-13b-3 


\section{References}

Adams, G. E., Boag, J. W., Currant, J. and Michael, B. D.: Absolute rate constants for the reaction of the hydroxyl radical with organic compounds, Pulse Radiolysis, edited by M. Ebert, pp. 131-143, Academic Press, New York., 1965.

Berger, P., Karpel Vel Leitner, N., Doré, M. and Legube, B.: Ozone and hydroxyl radicals induced oxidation of glycine, Water Research, doi:10.1016/S0043-1354(98)00230-9, 1999.

Bianco, A., Passananti, M., Deguillaume, L., Mailhot, G. and Brigante, M.: Tryptophan and tryptophan-like substances in cloud water: Occurrence and photochemical fate, Atmospheric Environment, doi:10.1016/j.atmosenv.2016.04.034, 2016.

Buxton, G. V., Greenstock, C. L., Helman, W. P. and Ross, A. B.: Critical Review of rate constants for reactions of hydrated electrons, hydrogen atoms and hydroxyl radicals $\left(\cdot \mathrm{OH} / \cdot \mathrm{O}^{-}\right.$ in Aqueous Solution, Journal of Physical and Chemical Reference Data, doi:10.1063/1.555805, 1988.

Ignatenko, A. V. and Cherenkevich, S. N.: Reactivity of amino-acidsand proteins in reactions with ozone., Kinetics and Catalysis, 1985.

KEGG pathway database: No Title, n.d.

Kraljić, I. and Sharpatyi, V. A.: Determination of singlet oxygen rate constants in aqueous solutions, Photochemistry and Photobiology, doi:10.1111/j.1751-1097.1978.tb06973.x, 1978.

Marion, A., Brigante, M. and Mailhot, G.: A new source of ammonia and carboxylic acids in cloud water: The first evidence of photochemical process involving an iron-amino acid complex, Atmospheric Environment, doi:10.1016/j.atmosenv.2018.09.060, 2018.

MASUDA, T., NAKANO, S. and KONDO, M.: Rate Constants for the Reactions of OH Radicals with the Enzyme Proteins as Determined by the p-Nitrosodimethylaniline Method, Journal of Radiation Research, doi:10.1269/jrr.14.339, 1973.

Matheson, I. B. C. and Lee, J.: Chemical recation rates of amino acids with singlet oxygen, Photochemistry and Photobiology, doi:10.1111/j.1751-1097.1979.tb07786.x, 1979.

McGregor, K. G. and Anastasio, C.: Chemistry of fog waters in California's Central Valley: 2. Photochemical transformations of amino acids and alkyl amines, Atmospheric Environment, doi:10.1016/S1352-2310(00)00282-X, 2001.

Michaeli, A. and Feitelson, J.: Reactivity of singlet oxygen toward amino acids and peptides, Photochemistry and Photobiology, doi:10.1111/j.1751-1097.1994.tb05035.x, 1994.

Miskoski, S. and García, N. A.: Influence of the peptide bond on the singlet molecular oxygen mediated (I (O2[g]) Photooxidation of histidine and methionine dipeptides. A kinetic study, Photochemistry and Photobiology, doi:10.1111/j.1751-1097.1993.tb02317.x, 1993.

Morgan, P. E., Pattison, D. I. and Davies, M. J.: Quantification of hydroxyl radical-derived oxidation products in peptides containing glycine, alanine, valine, and proline, Free Radical Biology and Medicine, doi:10.1016/j.freeradbiomed.2011.10.448, 2012. 
Motohashi, N. and Saito, Y.: Competitive Measurement of Rate Constants for Hydroxyl Radical Reactions Using Radiolytic Hydroxylation of Benzoate, Chemical and Pharmaceutical Bulletin, doi:10.1248/cpb.41.1842, 1993.

Mudd, J. B., Leavitt, R., Ongun, A. and McManus, T. T.: Reaction of ozone with amino acids and proteins, Atmospheric Environment (1967), doi:10.1016/0004-6981(69)90024-9, 1969.

Pattison, D. I., Rahmanto, A. S. and Davies, M. J.: Photo-oxidation of proteins, Photochem. Photobiol. Sci., 11(1), 38-53, doi:10.1039/C1PP05164D, 2012.

Prasse, C., Ford, B., Nomura, D. K. and Sedlak, D. L.: Unexpected transformation of dissolved phenols to toxic dicarbonyls by hydroxyl radicals and UV light, Proceedings of the National Academy of Sciences of the United States of America, doi:10.1073/pnas.1715821115, 2018.

Prütz, W. A. and Vogel, S. V.: Specific Rate Constants of Hydroxyl Radical and Hydrated Electron Reactions Determined by the RCL Method, Zeitschrift fur Naturforschung - Section B Journal of Chemical Sciences, doi:10.1515/znb-1976-1115, 1976.

Pryor, W. A., Giamalva, D. H. and Church, D. F.: Kinetics of ozonation. 2. Amino acids and model compounds in water and comparisons to rates in nonpolar solvents, J. Am. Chem. Soc., 106(23), 7094-7100, doi:10.1021/ja00335a038, 1984.

Scholes, G., Shaw, P., Wilson, R. L. and Ebert, M.: Pulse radiolysis studies of aqueous solutions of nucleic acid and related substances., in Pulse Radiolysis, pp. 151-164, Academic Press., 1965.

Solar, S., Solar, W. and Getoff, N.: Reactivity of OH with tyrosine in aqueous solution studied by pulse radiolysis, Journal of Physical Chemistry, doi:10.1021/j150654a030, 1984.

Stadtman, E. R.: Oxidation of Free Amino Acids and Amino Acid Residues in Proteins by Radiolysis and by Metal-Catalyzed Reactions, Annual Review of Biochemistry, doi:10.1146/annurev.bi.62.070193.004053, 1993.

Stadtman, E. R. and Levine, R. L.: Free radical-mediated oxidation of free amino acids and amino acid residues in proteins, Amino Acids, doi:10.1007/s00726-003-0011-2, 2003. 